University of Nebraska - Lincoln

DigitalCommons@University of Nebraska - Lincoln

$1-1-1995$

\title{
Melengestrol Acetate at Greater Doses Than Typically Used for Estrous Synchrony in Bovine Females Does Not Mimic Endogenous Progesterone in Regulation of Secretion of Luteinizing Hormone and $17 \beta$-Estradiol
}

\author{
F. N. Kojima \\ University of Nebraska-Lincoln \\ J. R. Chenault \\ The Upjohn Company, Kalamazoo, Michigan \\ M. E. Wehrman \\ University of Nebraska-Lincoln \\ E. G. M. Bergfeld \\ University of Nebraska-Lincoln, ebergfeld@sciencesocieties.org \\ Andrea S. Cupp \\ University of Nebraska-Lincoln, acupp2@unl.edu

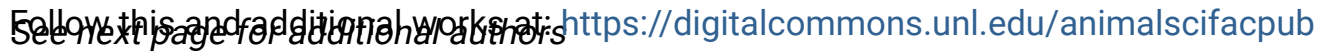 \\ Part of the Animal Sciences Commons
}

Kojima, F. N.; Chenault, J. R.; Wehrman, M. E.; Bergfeld, E. G. M.; Cupp, Andrea S.; Werth, L. A.; Mariscal, V.; Sanchez, T.; Kittok, Roger J.; and Kinder, J. E., "Melengestrol Acetate at Greater Doses Than Typically Used for Estrous Synchrony in Bovine Females Does Not Mimic Endogenous Progesterone in Regulation of Secretion of Luteinizing Hormone and 17ß-Estradiol" (1995). Faculty Papers and Publications in Animal Science. 187.

https://digitalcommons.unl.edu/animalscifacpub/187

This Article is brought to you for free and open access by the Animal Science Department at DigitalCommons@University of Nebraska - Lincoln. It has been accepted for inclusion in Faculty Papers and Publications in Animal Science by an authorized administrator of DigitalCommons@University of Nebraska - Lincoln. 


\section{Authors}

F. N. Kojima, J. R. Chenault, M. E. Wehrman, E. G. M. Bergfeld, Andrea S. Cupp, L. A. Werth, V. Mariscal, T. Sanchez, Roger J. Kittok, and J. E. Kinder 


\title{
Melengestrol Acetate at Greater Doses Than Typically Used for Estrous Synchrony in Bovine Females Does Not Mimic Endogenous Progesterone in Regulation of Secretion of Luteinizing Hormone and 17 $\beta$-Estradiol ${ }^{1}$
}

\author{
F.N. KOJIMA, ${ }^{5}$ J.R. CHENAULT, ${ }^{6}$ M.E. WEHRMAN, ${ }^{5}$ E.G. BERGFELD, ${ }^{5}$ A.S. CUPP, ${ }^{5}$ L.A. WERTH, ${ }^{3,5}$ V. MARISCAL, \\ T. SANCHEZ, ${ }^{4,5}$ R.J. KITTOK, ${ }^{5}$ and J.E. KINDER ${ }^{2,5}$
}

\author{
Department of Animal Science, ${ }^{5}$ University of Nebraska-Lincoln, Lincoln, Nebraska 68583-0908 \\ The Upjohn Company, ${ }^{6}$ Kalamazoo, Michigan 49001
}

\begin{abstract}
Our working hypothesis was that doses of melengestrol acetate (MGA) greater than those typically administered in estrous synchrony regimens would regulate secretion of $\mathrm{LH}$ and $17 \boldsymbol{\beta}$-estradiol $\left(\mathrm{E}_{2}\right)$ as endogenous progesterone $\left(\mathrm{P}_{4}\right)$ does during the midluteal phase of the estrous cycle. We also hypothesized that endogenous $P_{4}$ from the CL would interact with MGA to further decrease the frequency of LH pulses and $E_{2}$. Cows on Day 5 of their estrous cycle (Day $0=$ estrus) were randomly assigned to an untreated control group (CONT, $n=5$ ) or to one of six MGA treatment groups ( $n=5$ per group): 1) MGA administered orally each day via a gelatin capsule at a dose of $0.5 \mathrm{mg} \mathrm{MGA} / \mathrm{cow}$ with the $\mathrm{CL}$ present $(0.5 \mathrm{CL}) ; 2) 0.5 \mathrm{mg}$ MGA/cow daily in the absence of CL (0.5NO); 3) $1.0 \mathrm{mg}$ MGA with CL present (1.0CL); 4) $1.0 \mathrm{mg}$ MGA without CL (1.0NO); 5) $1.5 \mathrm{mg}$ MGA with CL present (1.5CL); 6) $1.5 \mathrm{mg}$ without CL (1.5NO). MGA was administered for 10 days (Day $5=$ initiation of treatment). To regress CL, cows assigned to groups without $\mathrm{CL}$ received injections of prostaglandin $\mathrm{F}_{2 \alpha}\left(\mathrm{PGF}_{2 \alpha} ; 25 \mathrm{mg}\right.$ ) on Days 6 and 7 of their estrous cycle. All cows were administered $\mathrm{PGF}_{2 \alpha}$ at the end of the 10-day treatment period. During the treatment period, daily blood samples were collected to determine concentrations of $\mathrm{E}_{2}$. Serial blood samples were collected at 15 -min intervals for $24 \mathrm{~h}$ on Days 8, 11, and 14 to determine pattern of $\mathrm{LH}$ secretion. Frequency of LH pulses on Days 8, 11, and 14 was greater $(p<0.05)$ in cows without $\mathrm{CL}(0.5 \mathrm{NO}, 1.0 \mathrm{NO}$, and $1.5 \mathrm{NO})$ than in cows with CL $(0.5 \mathrm{CL}, 1.0 \mathrm{CL}, 1.5 \mathrm{CL}$, and CONT). Mean concentrations of LH were greater $(p<0.05)$ in cows from the $0.5 \mathrm{NO}$ group on Days 8 and 11 and were greater $(p<0.05)$ in cows from the $0.5 \mathrm{NO}, 1.0 \mathrm{NO}$, and $1.5 \mathrm{NO}$ groups on Day 14 as compared to cows with CL. Overall mean concentrations of LH across Days 8,11 , and 14 were greatest $(p<0.05)$ in cows from the $0.5 N O$ group and were also greater $(p<0.05)$ in cows from the 0.5NO, 1.0NO, and $1.5 \mathrm{NO}$ groups as compared to cows in the 0.5CL, 1.0CL, 1.5CL, and CONT groups. Mean concentrations of $\mathrm{E}_{2}$ during the treatment period were greater $(p<0.05)$ in cows from the $0.5 \mathrm{NO}$ group than in cows from either the $1.0 \mathrm{NO}$ or the $1.5 \mathrm{NO}$ group; these values were also greater $(p<0.05)$ in cows of the $0.5 \mathrm{NO}, 1.0 \mathrm{NO}$, and $1.5 \mathrm{NO}$ groups as compared to cows of the $1.0 \mathrm{CL}$ and CONT groups. Therefore, we reject our working hypothesis because doses of MGA greater than those typically used in estrous synchrony protocols did not suppress $\mathrm{LH}_{\mathrm{H}}$ and $\mathrm{E}_{2}$ to the same extent that endogenous $\mathrm{P}_{4}$ does. In addition, MGA treatment when CL were present did not result in a further suppression of $\mathrm{LH}$ pulse frequency or of $E_{2}$ as compared to the values in control cows with functional $\mathrm{Cl}$.
\end{abstract}

\section{INTRODUCTION}

Melengestrol acetate (MGA), an orally active synthetic progestin, has been utilized to synchronize time of ovulation and time of behavioral estrus in cattle [1-4]. However, treatment with MGA has often been associated with reduced fertility when cows are inseminated at the synchronized estrus that ensues immediately after termination of MGA administration [1-6]. The possible factors that may influence conception rates at the synchronized estrus after use of MGA include an increased size of dominant ovarian follicle(s) $[7,8]$ that do not ovulate during the MGA treatment period [7-9]. Associated with the increased size of

Accepted October 6, 1994.

Received June 9, 1994

${ }^{1}$ Published as paper No, 10710, Journal Ser. Nebraska Agr. Res. Div,; Research supported by appropriated funding, State of Nebraska.

${ }^{2}$ Correspondence: James E. Kinder, A224j Animal Sciences, University of Ne. braska-Lincoln, Lincoln, NE 68583-0908. FAX: (402) 472-6362.

${ }^{3}$ Current address: Department of Veterinary and Biomedical Sciences, University of Nebraska-Lincoln, Lincoln, NE 68583-0905.

Current address: Centro de Ganaderia, Colegio de Postgraduados, Chapingo, Mexico, C.P. 56230. dominant ovarian follicle(s), increased concentrations of $17 \beta$ estradiol $\left(\mathrm{E}_{2}\right)$ in peripheral circulation during and immediately after MGA treatment have also been reported [1013]. A reduction in size and weight of the CL on Day 3 of the estrous cycle after MGA treatment has also been reported [9].

Few studies have evaluated the influence of MGA on secretory pattern of gonadotropins, particularly LH. In general, the pattern of pulsatile secretion of $\mathrm{LH}$ in the bovine female is modulated by the ovarian steroids $\mathrm{E}_{2}$ and progesterone $\left(\mathrm{P}_{4}\right)[14,15]$. Administration of low doses of $\mathrm{P}_{4}$ $(2-3 \mathrm{ng} / \mathrm{ml}$ in plasma) to cows in the absence of $\mathrm{CL}$ was reported to result in a greater frequency of LH pulses and increased concentrations of $\mathrm{E}_{2}$ compared to those of control cows with functional CL $[13,16]$. Onset of the preovulatory surge of LH was subsequently shown to be earlier after removal of $\mathrm{P}_{4}$ treatment in cows receiving a low dose as compared to those receiving greater doses of $P_{4}(7-10$ $\mathrm{ng} / \mathrm{ml}$ in plasma) $[13,16]$. Treatment with lower doses of $\mathrm{P}_{4}$ for a duration sufficient to extend the estrous cycle has resulted in alterations in patterns of ovarian follicular dy- 
TABLE 1. Frequency of LH pulses during serial blood collections on Days 8,11 , and 14 post estrus.

\begin{tabular}{lccccc}
\hline & & \multicolumn{4}{c}{ Frequency of LH pulses/24 $h^{\mathrm{a}}$} \\
\cline { 3 - 6 } Treatment $^{\mathrm{b}}$ & $\mathrm{n}$ & Day 8 & Day 11 & Day 14 & $\begin{array}{c}\text { Overall } \\
\text { mean }\end{array}$ \\
\hline $0.5 \mathrm{CL}$ & 5 & $5.0^{\mathrm{d}}$ & $4.4^{\mathrm{e}}$ & $3.4^{\mathrm{d}}$ & $4.3^{\mathrm{d}}$ \\
$0.5 \mathrm{NO}$ & 5 & $16.6^{\mathrm{c}}$ & $18.0^{\mathrm{c}}$ & $17.6^{\mathrm{c}}$ & $17.4^{\mathrm{c}}$ \\
$1.0 \mathrm{CL}$ & 5 & $3.4^{\mathrm{d}}$ & $3.6^{\mathrm{e}}$ & $3.6^{\mathrm{d}}$ & $3.5^{\mathrm{d}}$ \\
$1.0 \mathrm{NO}$ & 4 & $16.8^{\mathrm{c}}$ & $13.8^{\mathrm{d}}$ & $13.0^{\mathrm{c}}$ & $14.5^{\mathrm{c}}$ \\
$1.5 \mathrm{CL}$ & 4 & $5.8^{\mathrm{e}}$ & $7.3^{\mathrm{d}}$ & $6.9^{\mathrm{d}}$ \\
$1.5 \mathrm{NO}$ & 4 & $13.0^{\mathrm{c}}$ & $12.8^{\mathrm{d}}$ & $13.0^{\mathrm{c}}$ & $12.9^{\mathrm{c}}$ \\
CONT & 4 & $6.0^{\mathrm{d}}$ & $4.5^{\mathrm{e}}$ & $4.5^{\mathrm{d}}$ & $5.0^{\mathrm{d}}$ \\
Pooled SEM & & 1.3 & 1.3 & 1.6 & 0.8 \\
\hline
\end{tabular}

Determined with Pulsar software.

bee Materials and Methods for definitions of abbreviations and explanation of treatment regimens.

cde Numbers with differing superscripts within column differ $(p<0.05)$.

namics and prolonged maintenance of the largest follicle that was dominant at the time of administration of $\mathrm{P}_{4}$; $\mathrm{CO}$ incidental increases in concentrations of $\mathbf{E}_{2}$ were also observed [17].

We previously reported [13] that treatment of cows with MGA in the absence of $\mathrm{CL}$ at a dose of $0.5 \mathrm{mg} /$ day, which is the dose used in estrous synchrony programs, resulted in frequency of $\mathrm{LH}$ pulses and concentrations of $E_{2}$ in plasma that were similar to those observed in cows treated with low doses of $\mathrm{P}_{4}$. Frequency of $\mathrm{LH}$ pulses and concentrations of $E_{2}$ were greater in cows treated with MGA than in cows with functional $\mathrm{CL}$ that were in the midluteal phase of their estrous cycle.

Therefore, our working hyporhesis was that doses of MGA greater than those presently used in estrous synchrony programs would regulate frequency of LH pulses and concentrations of $E_{2}$ in a manner similar to that of endogenous $P_{4}$ from $\mathrm{CL}$ during the midluteal phase of the estrous cycle. We also hypothesized that endogenous $\mathrm{P}_{4}$ from the $\mathrm{CL}$ would interact with MGA to further decrease the frequency of $\mathrm{LH}$ pulses and peripheral concentrations of $E_{2}$.

\section{MATERIALS AND METHODS}

\section{Experimental Protocol}

Thirty-five mature nonlactating beef cows of a composite breed type (1/4 Hereford, 1/4 Angus, 1/4 Pinzgauer, 1/4 Red Poll) exhibiting normal estrous cycles were used in this study (3-11 yr of age; $489 \pm 12 \mathrm{~kg} \mathrm{BW}$, mean \pm SEM). Stage of the estrous cycle was synchronized in all cows before initiation of treatments by administration of two injections of prostaglandin $\mathrm{F}_{2 \alpha}\left(\mathrm{PGF}_{2 \alpha}, 25 \mathrm{mg}\right.$; Lutalyse Sterile Solution; Upjohn Co., Kalamazoo, MI) 11 days apart. Cows on Day 5 of their estrous cycle (Day $0=$ estrus) were randomly assigned to an untreated control group (CONT, $\mathrm{n}=$ 5) or to one of six MGA treatment groups $(n=5 /$ group): 1) MGA (MGA 200 Premix, Upjohn Co.) administered orally each day via a gelatin capsule at a dose of $0.5 \mathrm{mg} \mathrm{MGA} /$ cow with $\mathrm{CL}$ present $(0.5 \mathrm{CL})$; 2) $0.5 \mathrm{mg} \mathrm{MGA} / \mathrm{cow}$ daily without CL (0.5NO); 3) $1.0 \mathrm{mg} \mathrm{MGA}$ with CL present (1.0CL);
4) $1.0 \mathrm{mg}$ MGA without CL (1.0NO); 5) $1.5 \mathrm{mg}$ MGA with CL present (1.5CL); 6) $1.5 \mathrm{mg}$ without CL (1.5NO). The gelatin capsule was used to ensure that cows received specific doses of MGA relative to the treatment groups to which they were assigned. Treatments were initiated on Day 5 of the estrous cycle and cows received the assigned dosage of MGA every morning $(0800 \mathrm{~h})$ for 10 days. Cows assigned to the CONT group received an empty gelatin capsule at the same time. Therefore, cows from the CONT group were in the luteal phase (from Day 5 to Day 15) of the estrous cycle during the treatment period. Cows assigned to the groups without $\mathrm{CL}$ received injections of $\mathrm{PGF}_{2 \alpha}(25 \mathrm{mg})$ on Days 6 and 7 for regression of the CL to eliminate endogenous $\mathrm{P}_{4}$ from the $\mathrm{CL}$. During the initial estrous synchronization before treatments began, four cows that exhibited behavioral estrus were assigned to 1.0NO, 1.5CL, 1.5NO, and CONT groups (one cow per group); however, these cows did not respond to the injections of $\mathrm{PGF}_{2 \alpha} 11$ days apart at the initial estrous synchronization before the treatment period as determined by examination of profiles of $\mathrm{P}_{4}$ concentration from Day -3 to Day 50. Data for these cows were, therefore, eliminated from the statistical analyses.

On Days 8, 11, and 14 after estrus, catheters were inserted in the jugular vein of all cows, and blood samples were collected at 15 -min intervals for $24 \mathrm{~h}$. These blood samples were used to determine pulse frequency of $\mathrm{LH}$. On Day 15, simultaneously with the last dose of MGA, all cows received an injection of $25 \mathrm{mg} \mathrm{PGF}{ }_{2 \alpha}$ (Hour 0 ). Blood samples were collected at 3-h intervals beginning at Hour 40 (Day 17) and continuing through Hour 169 (Day 22). These blood samples were used to determine the interval to preovulatory surges of LH. Blood samples collected at 15-min and 3-h intervals were allowed to clot at room temperature and then stored at $4^{\circ} \mathrm{C}$ for $24 \mathrm{~h}$. Samples were then centrifuged at $1520 \times g$ for $15 \mathrm{~min}$, and serum was decanted and stored at $-20^{\circ} \mathrm{C}$ until assayed for LH.

Daily blood samples were collected in tubes treated with a $30 \%$ solution of EDTA ( $50 \mu \mathrm{l}$ for a $10-\mathrm{ml}$ blood sample; Fisher Scientific, Fair Lawn, NJ) from all cows throughout the treatment period and for 35 days post-treatment (from 
Day -3 to Day 50 ) in order to evaluate plasma concentrations of $\mathrm{P}_{4}$ and $\mathrm{E}_{2}$ during the treatment period and the estrous cycle following cessation of treatments. In an attempt to avoid possible degradation of $\mathrm{P}_{4}$ in blood, these samples were placed on ice immediately and plasma was separated from blood cells by centrifugation at $1520 \times g$ for $15 \mathrm{~min}$ within $1 \mathrm{~h}$ of collection. Plasma was then collected and stored at $-20^{\circ} \mathrm{C}$ until assayed for $\mathrm{P}_{4}$ and $\mathrm{E}_{2}$. In addition, all cows were observed for behavioral estrus three times a day at approximately 0600,1200 , and $1800 \mathrm{~h}$ from Day -5 to Day 50.

\section{RIAS}

Concentrations of $\mathrm{LH}$ in all samples collected serially on Days 8,11 , and 14 were analyzed by RIA $[18,19]$. Intra- and interassay coefficients of variation for LH assays were 2.7 and $10.0 \%$, respectively. Assay sensitivity was $12 \mathrm{pg} / \mathrm{ml}$ of serum. Concentrations of FSH in all pooled serum samples were analyzed by RIA $[19,20]$. Intra- and interassay coefficients of variation for FSH assays were 2.3 and $4.7 \%$, respectively, and assay sensitivity was $56 \mathrm{pg} / \mathrm{ml}$ of serum. Concentrations of $\mathrm{P}_{4}$ in plasma samples collected throughout the experiment were analyzed by RIA [16]. Intra- and interassay coefficients of variation for $\mathrm{P}_{4}$ assays were 2.3 and $17.6 \%$, respectively; assay sensitivity was $312 \mathrm{pg} / \mathrm{ml}$ of plasma. Concentrations of $E_{2}$ in plasma samples collected throughout the experiment were also analyzed by RLA [13]. Intraand interassay coefficients of variation for $\mathrm{E}_{2}$ assays were 3.9 and $18.2 \%$, respectively, and assay sensitivity was $0.6 \mathrm{pg} /$ $\mathrm{ml}$ of plasma.

\section{Data Reduction and Statistical Analysis}

Mean concentrations of $\mathrm{LH}(\mathrm{ng} / \mathrm{ml})$ in serum samples, frequency of pulses of LH (pulses $/ 24 \mathrm{~h}$ ), and amplitude of pulses of $\mathrm{LH}(\mathrm{ng} / \mathrm{ml})$ were determined through the use of algorithms (Pulsar software modified for the IBM-PC by J.F. Gitzen and V.D. Ramirez, Urbana, IL). The $\mathrm{G}$ values used for the Pulsar program were 6.8, 4.4, 1.6, 1.3, and 10.0 for $G(1)$ through $G(5)$, respectively. Interval to the initiation of the preovulatory surge of $\mathrm{LH}$ was defined as the number of hours between administration of the last dose of MGA and/or injection of $\mathrm{PGF}_{2 \alpha}$ and the initiation of a continuous high-amplitude rise in concentrations of LH. Area under the curve for the profile of $\mathrm{P}_{4}$ during the treatment period (Days 5-15) was determined by measurement with a planimeter. The length of the estrous cycle following cessation of treatment was determined by examination of profiles for $\mathrm{P}_{4}$ and $\mathrm{E}_{2}$ concentrations and by observations for behavioral estrus during this period.

Data on the pulsatile secretion of $\mathrm{LH}$, the concentrations of $\mathrm{P}_{4}$ and $\mathrm{E}_{2}$ on Days 8,11 , and 14 , area under the curve for the profile of $\mathrm{P}_{4}$, interval to the preovulatory surge of $\mathrm{LH}$, and length of estrous cycle following cessation of treatment were analyzed as a completely randomized design [21]
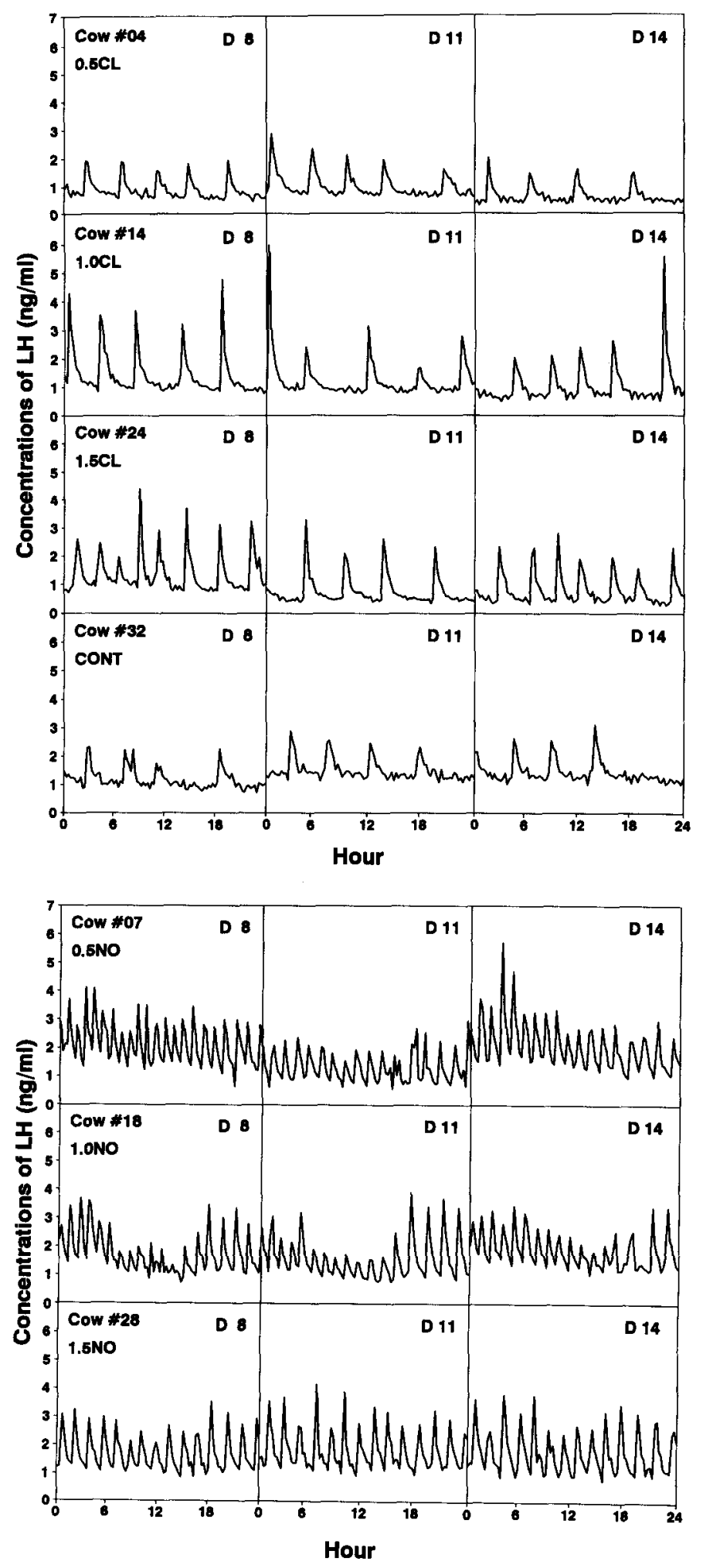

FIG. 1. Secretory profile of LH (15-min intervals for $24 \mathrm{~h})$ from individual representative cows from each treatment group during serial blood collections on Days 8, 11, and 14 after estrus. 
TABLE 2. Mean concentrations of LH during serial blood collections on Days 8,11 , and 14 post estrus and mean concentration of FSH during treatment.

\begin{tabular}{|c|c|c|c|c|c|c|}
\hline \multirow[b]{2}{*}{ Treatment $^{\mathrm{b}}$} & \multirow[b]{2}{*}{ 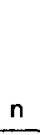 } & \multicolumn{4}{|c|}{ Mean concentrations of $\mathrm{LH}(\mathrm{ng} / \mathrm{ml})^{\mathrm{a}}$} & \multirow{2}{*}{$\begin{array}{l}\text { Mean FSH } \\
\text { during } \\
\text { treatment } \\
(\mathrm{ng} / \mathrm{ml})^{c}\end{array}$} \\
\hline & & Day 8 & Day 11 & Day 14 & $\begin{array}{l}\text { Overall } \\
\text { mean }\end{array}$ & \\
\hline $0.5 \mathrm{CL}$ & 5 & $1.03^{\mathrm{f}}$ & $1.00^{\text {et }}$ & $0.89^{\mathrm{e}}$ & $0.97^{4}$ & 1.92 \\
\hline $0.5 \mathrm{NO}$ & 5 & $2.60^{\mathrm{d}}$ & $2.13^{d}$ & $2.10^{\mathrm{d}}$ & $2.27^{\mathrm{d}}$ & 2.07 \\
\hline $1.0 \mathrm{CL}$ & 5 & $1.11^{\mathrm{ef}}$ & $0.94^{f}$ & $1.01^{8}$ & $1.02^{f}$ & 1.83 \\
\hline $1.0 \mathrm{NO}$ & 4 & $1.62^{\mathrm{de}}$ & $1.42^{\text {ef }}$ & $1.75^{\circ}$ & $1.60^{\mathrm{e}}$ & 2.13 \\
\hline $1.5 \mathrm{CL}$ & 4 & $1.27^{\text {ef }}$ & $0.84^{f}$ & $1.10^{\mathrm{e}}$ & $1.07^{f}$ & 1.88 \\
\hline $1.5 \mathrm{NO}$ & 4 & $1.64^{\mathrm{de}}$ & $1.58^{\mathrm{de}}$ & $1.71^{d}$ & $1.64^{\mathrm{e}}$ & 1.85 \\
\hline CONT & 4 & $1.08^{\text {ef }}$ & $1.17^{\mathrm{ef}}$ & $0.95^{\mathrm{e}}$ & $1.06^{f}$ & 1.97 \\
\hline Pooled SEM & & 0.17 & 0.19 & 0.18 & 0.10 & 0.13 \\
\hline
\end{tabular}

${ }^{a}$ Determined with Pulsar software.

'See Materials and Methods for definitions of abbreviations and explanation of treatment regimens,

'Concentrations of FSH did not differ among treatment groups or across days of treatment; therefore, data were pooled.

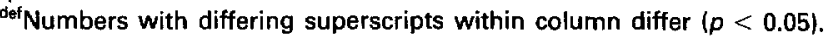

by ANOVA using the general linear models procedure of SAS [22]. Treatment means were compared by orthogonal contrasts and also Duncan's new multiple range test [21]. Pulse frequencies and mean concentrations of $\mathrm{LH}$ across Days 8,11 , and 14 and concentrations of $\mathrm{E}_{2}, \mathrm{P}_{4}$, and $\mathrm{FSH}$ during the treatment period were analyzed through the use of a mixed model procedure (Proc Mixed) of SAS [23]. The fitted model included treatment and day as fixed effects and cow as a random effect. To account for the covariance between observations from the same animal at different days, different options of covariance structures for residuals available in the Repeated Statement of Proc Mixed were considered, and the model with the best fit was chosen to analyze data. Comparison of means was performed by using Proc Mixed of SAS [23], which employs the $t$-test and also Duncan's new multiple range test [21].

\section{RESULTS}

\section{Hormone Concentrations during Serial Blood Collection Periods}

During the serial blood collection on Days 8,11 , and 14 after estrus, LH pulses occurred more frequently $(p<0.05)$ in the cows treated with all doses of MGA when $\mathrm{CL}$ were absent $(0.5 \mathrm{NO}, 1.0 \mathrm{NO}$, and $1.5 \mathrm{NO})$ as compared to cows with CL present (0.5CL, 1.0CL, 1.5CL, and CONT; Table 1). Frequency of LH pulses did not differ $(p>0.10)$ among cows with $\mathrm{CL}$ present $(0.5 \mathrm{CL}, 1.0 \mathrm{CL}, 1.5 \mathrm{CL}$, and CONT). The number of $\mathrm{LH}$ pulses observed during each of the three serial blood collections was correlated within individual cows $(r=0.912$; Fig. 1$)$. Mean concentrations of LH were greatest $(p<0.05)$ in cows from the $0.5 \mathrm{NO}$ group on Days 8 and 11 ; they were greater $(p<0.05)$ in cows from the $0.5 \mathrm{NO}$, $1.0 \mathrm{NO}$, and $1.5 \mathrm{NO}$ groups on Day 14 as compared to MGAtreated cows that had CL and as compared to cows from the CONT group (Table 2). Overall mean concentrations of LH across Days 8, 11, and 14 were greatest $(p<0.05)$ in cows from the $0.5 \mathrm{NO}$ group; they were also greater $(p<$ 0.05 ) in cows from the $0.5 \mathrm{NO}, 1.0 \mathrm{NO}$, and $1.5 \mathrm{NO}$ groups as compared to cows of the $0.5 \mathrm{CL}, 1.0 \mathrm{CL}, 1.5 \mathrm{CL}$, and CONT groups (Table 2). Amplitude of LH pulses was not different $(p>0.10)$ among cows of all treatment groups on either Days 8,11 , or 14 (Table 3 ). Mean concentrations of FSH during the treatment period did not differ $(p>0.10)$ among cows of all treatment groups (Table 2).

On Days 8 and 11 , mean concentrations of $\mathrm{E}_{2}$ were greater $(p<0.05)$ from the $0.5 \mathrm{NO}$ group as compared to the cows

TABLE 3. Amplitude of LH pulses during serial blood collections on Days 8, 11, and 14 post estrus.

\begin{tabular}{lcccc}
\hline & & \multicolumn{2}{c}{ Amplitude of LH pulses $(\mathrm{ng} / \mathrm{m} /)^{\mathrm{a}, \mathrm{b}}$} \\
\cline { 3 - 5 } Treatment $^{\mathrm{c}}$ & $\mathrm{n}$ & Day 8 & Day 11 & Day 14 \\
\hline $0.5 \mathrm{CL}$ & 5 & 1.52 & 1.58 & 1.28 \\
$0.5 \mathrm{NO}$ & 5 & 2.16 & 2.31 & 2.00 \\
$1.0 \mathrm{CL}$ & 5 & 2.44 & 1.63 & 1.67 \\
$1.0 \mathrm{NO}$ & 4 & 1.47 & 1.42 & 1.55 \\
$1.5 \mathrm{CL}$ & 4 & 1.52 & 1.72 & 1.75 \\
$1.5 \mathrm{NO}$ & 4 & 1.83 & 1.89 & 2.24 \\
CONT & 4 & 1.65 & 1.62 & 1.67 \\
Pooled SEM & & 0.50 & 0.47 & 0.35 \\
\hline
\end{tabular}

aDetermined with Pulsar software.

bAmplitude of LH pulses did not differ among treatment groups on Day 8, 11, or 14 post estrus.

'See Materials and Methods for definitions of abbreviations and explanation of treatment regimens. 
TABLE 4. Mean concentrations of $E_{2}$ during serial blood collections on Days 8, 11, and 14 post estrus.

\begin{tabular}{|c|c|c|c|c|c|}
\hline \multirow[b]{2}{*}{ Treatment $^{a}$} & \multirow[b]{2}{*}{$\mathbf{n}$} & \multicolumn{3}{|c|}{ Mean concentrations of $E_{2}(p g / m l)$} & \multirow{2}{*}{$\begin{array}{c}\text { Mean } E_{2} \\
\text { during } \\
\text { treatment } \\
\text { (pg/mi) }\end{array}$} \\
\hline & & Day 8 & Day 11 & Day 14 & \\
\hline $0.5 \mathrm{CL}$ & 5 & $8.4^{d}$ & $3.9^{\mathrm{e}}$ & $14.2^{\mathrm{bc}}$ & $6.9^{\text {cd }}$ \\
\hline $0.5 \mathrm{NO}$ & 5 & $20.8^{\mathrm{b}}$ & $26.5^{\mathrm{b}}$ & $22.7^{\mathrm{b}}$ & $18.4^{\mathrm{b}}$ \\
\hline $1.0 \mathrm{CL}$ & 5 & $10.3^{d}$ & $3.6^{e}$ & $6.5^{c}$ & $6.4^{\mathrm{d}}$ \\
\hline 1.0NO & 4 & $13.8^{\mathrm{bc}}$ & $12.8^{\mathrm{cd}}$ & $15.6^{\mathrm{bc}}$ & $11.1^{\mathrm{c}}$ \\
\hline $1.5 \mathrm{CL}$ & 4 & $8.6^{\mathrm{d}}$ & $9.5^{\mathrm{de}}$ & $12.4^{\mathrm{bc}}$ & $7.0^{\text {cd }}$ \\
\hline $1.5 \mathrm{NO}$ & 4 & $14.4^{\mathrm{bc}}$ & $17.4^{\mathrm{c}}$ & $13.2^{\mathrm{bc}}$ & $11.0^{\mathrm{c}}$ \\
\hline CONT & 4 & $8.3^{d}$ & $5.4^{\mathrm{de}}$ & $5.5^{c}$ & $6.5^{\mathrm{d}}$ \\
\hline Pooled SEM & & 2.8 & 2.5 & 3.6 & 1.4 \\
\hline
\end{tabular}

asee Materials and Methods for definitions of abbreviations and explanation of treatment regimens.

${ }^{b c d}$ Numbers with differing superscripts within column differ $(p<0.05)$.

with CL present. Mean concentrations of $\mathrm{E}_{2}$ during the treatment period were greater $(p<0.05)$ in cows from the $0.5 \mathrm{NO}$ group than in cows from either the $1.0 \mathrm{NO}$ or the $1.5 \mathrm{NO}$ group; these values were also greater $(p<0.05)$ in cows of $0.5 \mathrm{NO} 1.0 \mathrm{NO}$, and $1.5 \mathrm{NO}$ groups as compared to cows of 1.0CL and CONT groups (Table 4). Mean concentrations of $\mathrm{P}_{4}$ at the end of treatment (Day 14) were greater $(p<0.05)$ in cows from $0.5 \mathrm{CL}, 1.0 \mathrm{CL}, 1.5 \mathrm{CL}$, and CONT groups than cows from the $0.5 \mathrm{NO}, 1.0 \mathrm{NO}$, and $1.5 \mathrm{NO}$ groups (Table 5). Area under the curve for the profile of $\mathrm{P}_{4}$ during the treatment period (Days 5-15) was greater $(p<0.05)$ in cows from $0.5 \mathrm{CL}, 1.0 \mathrm{CL}$, and CONT groups compared to cows of $1.0 \mathrm{NO}$ and $1.5 \mathrm{NO}$ groups, while cows of the $1.5 \mathrm{CL}$ group did not differ from those of the other groups $(p>$ 0.10 ; Table 5). There was a nonsignificant dose response among cows treated with MGA in the absence of $\mathrm{CL}$, with area under the curve for the $\mathrm{P}_{4}$ profile decreasing as dose of MGA increased $(0.5 \mathrm{NO}, 227.0 \pm 113 ; 1.0 \mathrm{NO}, 134.7 \pm 24$; and $1.5 \mathrm{NO}, 105.1 \pm 30$ arbitrary units). These results indicated that the $\mathrm{CL}$ in all cows assigned to the no-CL groups had regressed as a result of the two injections of $\mathrm{PGF}_{2 \alpha}$ on Days 6 and 7. During the treatment period, hormone profiles $\left(E_{2}\right.$ and $\left.P_{4}\right)$ and observations for behavioral estrus indicated that none of these cows exhibited behavioral estrus or ovulated during treatment.

\section{Interval to the Preovulatory Surge of $L H$}

After cessation of treatments on Day 15, initiation of the preovulatory surge of LH was earlier $(p<0.05)$ in cows from the CONT $(90 \pm 10 \mathrm{~h})$ and $0.5 \mathrm{CL}(95 \pm 10 \mathrm{~h})$ groups than in cows from the 1.0CL ( $143 \pm 9 \mathrm{~h})$ and $1.5 \mathrm{CL}(158$ $\pm 12 \mathrm{~h}$ ) groups (Table 6 ). Only one cow from each group treated with $\mathrm{MGA}$ in the absence of $\mathrm{CL}(0.5 \mathrm{NO}, 1.0 \mathrm{NO}$, and $1.5 \mathrm{NO}$ ) had initiated a preovulatory surge of $\mathrm{LH}$ within the 169-h blood sampling period after cessation of treatments. Interestingly, cows exhibiting the preovulatory $\mathrm{LH}$ surge that had received MGA in the absence of CL had intervals much like those of cows given the same dose of MGA in the presence of CL (Table 6).

\section{Estrous Cycle Following Treatments}

Duration of the estrous cycle (number of days between behavioral estrus) after treatments was shorter $(p<0.05)$ in cows from the $1.5 \mathrm{NO}$ group compared to cows in other groups (0.5CL, 0.5NO, 1.0CL, 1.5CL, and CONT; Table 6). Abnormal function of CL was observed in eleven MGA-treated cows during the estrous cycle following treatments, and eight of these eleven cows were from the groups treated with MGA in the absence of the CL (Table 6). Five cows had a shortened estrous cycle of less than 14 days (Fig. 2c). One

TABLE 5. Mean concentrations of $P_{4}$ during serial blood collections on Days 8,11 , and 14 post estrus and area under the curve for the profile of $\mathrm{P}_{4}$ during the treatment period.

\begin{tabular}{|c|c|c|c|c|c|}
\hline \multirow[b]{2}{*}{ Treatment $^{a}$} & \multirow[b]{2}{*}{$\mathbf{n}$} & \multicolumn{3}{|c|}{ Mean concentrations of $P_{4}(\mathrm{ng} / \mathrm{ml})$} & \multirow{2}{*}{$\begin{array}{c}\text { Area }^{b} \\
\text { (units) }\end{array}$} \\
\hline & & Day 8 & Day 11 & Day 14 & \\
\hline $0.5 \mathrm{CL}$ & 5 & $5.00^{c d}$ & $5.69^{c}$ & $6.71^{\mathrm{c}}$ & $681.1^{\text {cd }}$ \\
\hline 0.5 NO & 5 & $0.56^{e}$ & $0.61^{d}$ & $0.44^{\mathrm{d}}$ & $227.0^{d \theta}$ \\
\hline $1.0 \mathrm{CL}$ & 5 & $6.33^{c}$ & $6.68^{c}$ & $5.04^{c}$ & $808.0^{\mathrm{c}}$ \\
\hline 1.0 NO & 4 & $0.63^{e}$ & $0.52^{\mathrm{d}}$ & $0.38^{d}$ & $134.7^{e}$ \\
\hline $1.5 \mathrm{CL}$ & 4 & $2.83^{\text {de }}$ & $3.70^{\text {cd }}$ & $4.42^{c}$ & $451.5^{\mathrm{cds}}$ \\
\hline $1.5 \mathrm{NO}$ & 4 & $0.49^{\mathrm{e}}$ & $0.51^{d}$ & $0.22^{\mathrm{d}}$ & $105.1^{e}$ \\
\hline CONT & 4 & $4.40^{\text {cd }}$ & $6.36^{c}$ & $7.38^{c}$ & $762.1^{\mathrm{c}}$ \\
\hline Pooled SEM & & 1.09 & 1.28 & 1.16 & 129.3 \\
\hline
\end{tabular}

a See Materials and Methods for definitions of abbreviations and explanation of treatment regimens. ${ }^{b}$ Area under the curve for concentrations of $P_{4}$ during treatment period as expressed in arbitrary units. cde Numbers with differing superscripts within column differ $(p<0.05)$. 
TABLE 6. Interval to the preovulatory surge of LH, duration of the estrous cycle and luteal function after cessation of treatment.

\begin{tabular}{|c|c|c|c|c|}
\hline \multirow[b]{2}{*}{ Treatment $^{\mathrm{B}}$} & \multirow[b]{2}{*}{$\begin{array}{c}\text { Interval } \\
\text { to } L H \\
\text { surge }(h)^{b, c}\end{array}$} & \multirow[b]{2}{*}{$\begin{array}{l}\text { Duration of } \\
\text { the estrous cycle } \\
\text { after cessation } \\
\text { of treatment }(\mathrm{d})^{\mathrm{d}}\end{array}$} & \multicolumn{2}{|c|}{$\begin{array}{l}\text { Abnormal } \mathrm{P}_{4} \text { profile } \\
\text { following treatment }\end{array}$} \\
\hline & & & $\begin{array}{l}\text { Number of cows } \\
\text { with shortened } \\
\text { estrous cycle }\end{array}$ & $\begin{array}{l}\text { Number of cows } \\
\text { with possible } \\
\text { luteinized } \\
\text { follicle }\end{array}$ \\
\hline $0.5 \mathrm{CL}$ & $95^{9}(n=4)$ & $19.3^{9} \quad(n=4)$ & 1 & 1 \\
\hline $0.5 \mathrm{NO}$ & $(85)^{i}(n=1)$ & $17.0^{g} \quad(n=3)$ & 1 & 2 \\
\hline $1.0 \mathrm{CL}$ & $143^{h}(n=5)$ & $20.0^{9} \quad(n=5)$ & 1 & 0 \\
\hline $1.0 \mathrm{NO}$ & $(142)^{i}(n=1)$ & $16.3^{\text {gh }}(n=4)$ & 2 & 0 \\
\hline $1.5 \mathrm{CL}$ & $158^{h}(n=3)$ & $19.8^{9} \quad$ (n $=4$ ) & 0 & 0 \\
\hline $1.5 \mathrm{NO}$ & $(157)^{i}(n=1)$ & $10.5^{\mathrm{h}} \quad(n=4)$ & 1 & 2 \\
\hline CONT & $90^{\circ}(n=4)$ & $19.0^{9} \quad(n=4)$ & 0 & 0 \\
\hline Pooled SEM & 10 & 2.1 & & \\
\hline
\end{tabular}

"See Materials and Methods for definition of abbreviations and explanation of treatment regimens.

'Number of cows initiating the preovulatory surge of LH during the $169 \mathrm{~h}$ blood collection after cessation of treatment. Interval of time from treatment cessation to initiation of the preovulatory surge of $\mathrm{LH}$.

dThe length of the estrous cycle following cessation of treatment was determined by examination of profiles for $P_{4}$ and $E_{2}$ concentrations and observations for behavioral estrus during this period.

${ }^{\circ}$ Cows had a shortened estrous cycle less than 14 days following treatment.

'Cows had a delayed initiation of the estrous cycle for more than 20 days post treatment and had more than $1 \mathrm{ng} /$ $\mathrm{ml}$ of $\mathrm{P}_{4}$ in plasma, indicating the possibility of a luteinized follicle in these animals.

g,h Numbers with differing superscripts within column differ $(p<0.05)$.

ine cow from each treatment group initiated a preovulatory surge of $\mathrm{LH}$ during $169 \mathrm{~h}$ blood collection.

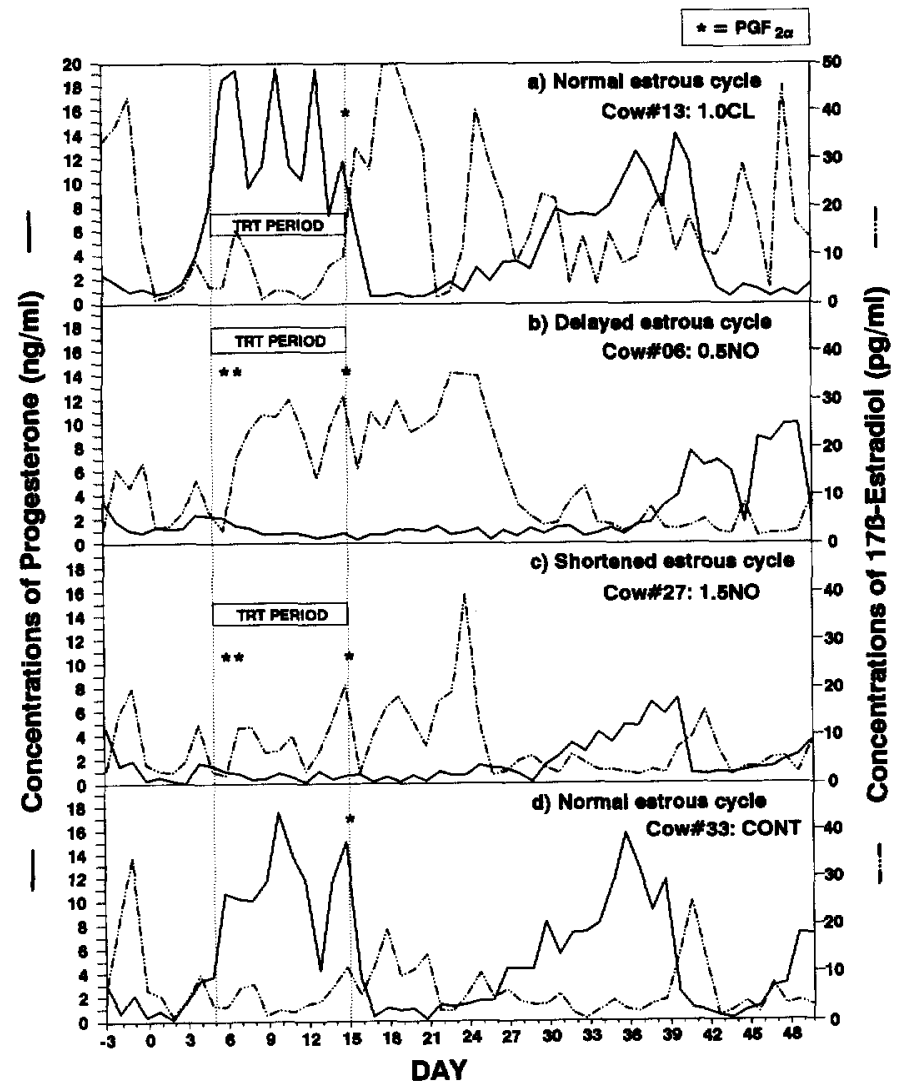

FIG. 2. Secretory profile of $P_{4}$ and $E_{2}$ from individual representative cows, during and after the treatment period, for (a) a normal estrous cycle after treatment with MGA (COW \#13; $1.0 \mathrm{CL}$ ); (b) delayed initiation of the next estrous cycle with a possible luteinized follicle (Cow \#06; 0.5NO); (c) a shortened estrous cycle, less than 14 days (Cow \#27; 1.5NO); and (d) a normal estrous cycle (Cow \#33; CONT). cow had reduced concentrations of $\mathrm{P}_{4}(2-3 \mathrm{ng} / \mathrm{ml})$ in plasma with a shortened estrous cycle of less than 14 days. Another five cows had delayed initiation of luteal function (more than 20 days post-treatment). These cows had $1-4 \mathrm{ng} / \mathrm{ml}$ of $\mathrm{P}_{4}$ in plasma over an extended period of time after the cessation of treatment, and profiles of $\mathrm{P}_{4}$ from these cows were unlike those for the typical estrous cycle (Fig. $2 \mathrm{~b} \mathrm{com-}$ pared to the control in Fig. 2d). In contrast, profiles of hormones in a typical estrous cycle from an MGA-treated cow and a control cow are shown in Figure 2, a and d, respectively.

\section{DISCUSSION}

In the present study, a greater frequency of LH pulses was observed in cows treated with all doses of MGA in the absence of $\mathrm{CL}(0.5 \mathrm{NO}, 1.0 \mathrm{NO}$, and $1.5 \mathrm{NO})$ during each of the three serial blood collections (Days 8, 11, and 14). This greater frequency of $\mathrm{LH}$ pulses is characteristic of the pattern of LH pulses normally observed during the follicular phase of the estrous cycle [24-26]. In addition, mean LH pulse frequencies pooled across all three serial blood collections in cows among the no-CL groups revealed a nonsignificant dose response trend with LH pulse frequency decreasing as dose of MGA increased (0.5NO, 17.4 \pm 0.5 ; $1.0 \mathrm{NO}, 14.5 \pm 1.0$; and $1.5 \mathrm{NO}, 12.9 \pm 0.6 \mathrm{LH}$ pulses $/ 24 \mathrm{~h}$ ). In contrast, frequency of LH pulses did not differ among cows treated with doses of MGA in the presence of CL or among controls (0.5CL, 1.0CL, 1.5CL, and CONT). During this period, mean concentrations of $\mathrm{P}_{4}$ were greater in cows from the $0.5 \mathrm{CL}, 1.0 \mathrm{CL}, 1.5 \mathrm{CL}$, and CONT groups than in those 
treated with MGA in the absence of the CL (0.5NO, 1.0NO, and $1.5 \mathrm{NO}$ ). This is in agreement with the secretory pattern of LH from previous studies that utilized treatment with either high or low doses of $P_{4}[13,16]$ or MGA in the absence of CL [13].

It has been reported that effects of synthetic progestins on the pattern of LH pulse frequency were abolished by the presence of $\mathrm{CL}$ [27]. These results indicate that the $\mathrm{CL}$ is the major factor controlling the secretory pattern of $\mathrm{LH}$ during the luteal phase of the estrous cycle. $\mathrm{P}_{4}$ is the major secretory product of the $\mathrm{CL}$, and MGA failed to modulate the release of $\mathrm{LH}$ in the same manner as a functional $\mathrm{CL}$ secreting $\mathrm{P}_{4}$. Therefore, the doses of MGA used in the present study do not mimic the ability of endogenous $\mathrm{P}_{4}$ to suppress the frequency of the $\mathrm{LH}$ pulse. However, all doses of MGA effectively blocked both the preovulatory surge of LH and ovulation. From these results, we postulate that MGA mimics the negative feedback of $\mathrm{P}_{4}$ in blocking the preovulatory surge of $\mathrm{LH}$ but not in suppressing pulsatile secretion of $\mathrm{LH}$, although there is a possibility that much higher doses of MGA might be able to suppress the pulsatile secretion of $\mathrm{LH}$.

On Days 8, 11, and 14, the greatest mean concentrations of $E_{2}$ were observed in cows from the $0.5 \mathrm{NO}$ group. This greater $\mathrm{E}_{2}$ probably resulted from greater frequencies of $\mathrm{LH}$ pulses in these cows (20.8:16.6, 26.5:18.0, and 22.7:17.6, pg of $\mathrm{E}_{2} / \mathrm{ml}: \mathrm{LH}$ pulses $/ 24 \mathrm{~h}$, respectively) as compared to cows of other groups. This is in agreement with results from a previous study [13] in which concentrations of $E_{2}$ and frequency of LH pulses were positively correlated. These greater concentrations of $E_{2}$ were similar to those observed during the late follicular phase of the estrous cycle just before the behavioral estrus and the preovulatory surge of $\mathrm{LH}[13,28-$ 30]. However, the greater concentrations of $E_{2}$ did not induce behavioral estrus during the treatment period in the present study. Therefore, the dose of MGA that blocks behavioral estrus is less than the dose required to suppress pulsatile secretion of $\mathrm{LH}$ to levels observed during the midluteal phase of the estrous cycle. An increase in plasma concentrations of $E_{2}$ in cows treated with the synthetic progestin in the absence of $\mathrm{CL}$ may be the result of less suppression on the LH pulse frequency, which resulted in enhanced ovarian follicular development and greater concentrations of $E_{2}$. Treatment with MGA has been shown to result in increased size of ovarian follicles $[7,8]$, estrogenic capacity [31], and concentrations of $E_{2}$ in plasma of cows $[11,12]$ via less suppression on the frequency of $L H$ pulses [13].

Use of real-time ultrasonography has indicated that treatment with MGA for a duration sufficient to extend the estrous cycle resulted in the development of ovarian follicles to larger sizes and in the persistence of dominant follicles for longer periods than are typical for dominant follicles during the luteal phase of the estrous cycle $[32,33]$. These larger ovarian follicles that develop during progestin-based estrous synchrony protocols have been termed "persistent follicles." The development of persistent ovarian follicles was first described during treatment with low doses of $\mathbf{P}_{\mathbf{4}}$, in the absence of $\mathrm{CL}$ [17], that dramatically altered the pattern of ovarian follicular dynamics. Persistent follicles have always been associated with greater concentrations of $E_{2}$ in the peripheral circulation and a greater frequency of $\mathrm{LH}$ pulses [34]. Interestingly, results from the present study indicated that secretion of FSH may not have a role in the formation of persistent follicles, at least in cows treated with MGA. Since the earlier studies, there have been numerous reports of the development of persistent follicles after treatment with various progestins [34-37]. Previous studies indicated that ovulation of a persistent follicle, brought about by treatment with either a low dose of $\mathrm{P}_{4}[37,38]$ or norgestomet in the absence of CL [39], resulted in reduced fertility at the synchronized estrus. Therefore, persistent ovarian follicles resulting from treatment with MGA may be a major factor contributing to reduced fertility rates if cows are inseminated at the first behavioral estrus that ensues after the termination of feeding this synthetic progestin.

The timing of the preovulatory surge of $\mathrm{LH}$ was earlier in cows from the CONT and $0.5 \mathrm{CL}$ groups than in cows from the 1.0CL and 1.5CL groups after cessation of treatments. Only one cow from each group treated with MGA in the absence of $\mathrm{CL}(0.5 \mathrm{NO}, 1.0 \mathrm{NO}$, and $1.5 \mathrm{NO})$ had initiated the preovulatory surge of LH within the 169-h blood sampling period. The intervals to the preovulatory surge of LH in these cows were very similar to those of cows given MGA in the presence of the CL. In general, the interval to the preovulatory surge of $\mathrm{LH}$ was prolonged as the dose of MGA increased. These results indicate that clearance of MGA may be closely associated with interval to the preovulatory surge of LH after treatment with MGA. These observations are explained by the fact that MGA is stored in adipose tissue of the body and released very slowly after the administration of MGA is ended [40].

After treatment ended, the duration of the estrous cycle was shorter in cows from the $1.5 \mathrm{NO}$ group compared to cows from the $0.5 \mathrm{CL}, 0.5 \mathrm{NO}, 1.0 \mathrm{CL}, 1.5 \mathrm{CL}$, and CONT groups. Abnormal function of $\mathrm{CL}$ was also observed in eleven MGAtreated cows, eight of these from groups treated with MGA in the absence of $\mathrm{CL}$. This is in agreement with previous reports of shortened estrous cycles [4] and subfunctional CL with reduced production of $\mathrm{P}_{4}[13]$ after treatment with MGA. It has also been reported that MGA resulted in reduced size and weight of CL at Day 3 but not at Day 13 of the subsequent estrous cycle [9].

In five cows, initiation of the estrous cycle was delayed for more than 20 days post-treatment and concentrations of $\mathrm{P}_{4}$ in plasma were greater than $1 \mathrm{ng} / \mathrm{ml}$ before the beginning of the next estrous cycle. Interestingly, we observed the same phenomenon in a previous study [13]. These results suggest the possibility that the elevated concentrations of $L H$ associated with MGA administration may induce lu- 
teinization of ovarian follicles that could account for the production of $\mathrm{P}_{4}$ observed in the present study [8]. Another consideration that could explain this observation is that an impaired or abnormal oocyte may reside in persistent ovarian follicles. This notion is supported by the observation that removal of the oocyte from Graafian follicles in situ promotes spontaneous luteinization and production of $\mathrm{P}_{4}$ by ovarian follicles in rabbits and rats [41-43]. It has also been reported that the mouse oocyte inhibits production of $\mathrm{P}_{4}$ by the cumulus oophorus in vitro [44]. Thus, prolonged periods of chronically elevated concentrations of $E_{2}$ during and after treatment with MGA may cause damage to the oocyte, which could promote spontaneous luteinization and production of $\mathrm{P}_{4}$ by these ovarian follicles. These luteinized ovarian follicles may persist for longer periods, thereby explaining the delayed initiation of the next estrous cycle after treatment with MGA.

In summary, the doses of MGA used in the present study did not suppress pulsatile secretion of $\mathrm{LH}$ as does endogenous $\mathrm{P}_{4}$ from the $\mathrm{CL}$. Alterations in ovarian biosynthetic processes are indicated by the increased secretion of $\mathrm{E}_{2}$ during and immediately after treatment with MGA. The increased frequency of LH pulses associated with MGA treatment in the absence of CL might result in the development of persistent follicles and the ovulation of abnormal oocytes, accounting for the reduction in fertility observed in cattle bred at the synchronized estrus. Treatment with MGA possibly causes luteinization of ovarian follicles and induced abnormal luteal function. Therefore, data from the present study indicate that if MGA is used alone, even at greater doses than presently used for estrous synchronization, fertility at the synchronized estrus may be compromised.

\section{ACKNOWLEDGMENTS}

We thank Robin Hopper-Faisal for her secretarial skills in preparing this manuscript; Karl Moline, Bob Browleit, and Jeff Bergman for managing the experimental animals; and Ken Pearson and Deb Clopton for technical assistance with hormone analysis. We also thank Dr. Jerry Reeves for LH antisera; Dr. Leo Reichert, Jr. for the purified $\mathrm{LH}_{;}$Dr. James Dias for FSH antisera; Dr. Norman Mason for $\mathrm{E}_{2}$ antisera; Dr. $\mathrm{H}$. Edward Grotjan, Jr. for the Four Fit Program used in the $\mathrm{E}_{2}$ assay analysis; and Upjohn Co. for providing the MGA 200 Premix and Lutalyse Sterile Solution. Very special thanks go to all undergraduate students for countless hours of help during this experiment.

\section{REFERENCES}

1. Lauderdale JW. Fertility and sperm transport following prostaglandin or progestogen treatment of cattle. INSERM 1973; 26:499-512.

2. Patterson DJ, Kiracofe GH, Stevenson JS, Corah LR. Control of the bovine estrous cycle with melengestrol acetate (MGA): a review. J Anim Sci 1989; 67:1895-1906.

3. Odde KG. A review of synchronization of estrus in postpartum cattle. J Anim Sci $1990 ; 68: 817-830$.

4. Zimbelman RG, Smith LW. Control of ovulation in cattle with melengestrol acetate. I. Effect of dosage and route of administration. J Reprod Fertil 1966; 11:185191.

5. Hansel W, Donaldson LE, Wagner WC, Brunner MA. A comparison of estrous cycle synchronization methods in beef cattle under feedlot conditions. J Anim Sci $1966 ; 25: 497-503$.
6. Zimbelman RG, Lauderdale JW, Sokolowski JH, Schalk TG. Safety and pharmacological evaluations of melengestrol acetate in cattle and other animals: a review. I Am Vet Med Assoc 1970; 157:1528-1536.

7. Zimbelman RG, Smith LW. Control of ovulation in cattle with melengestrol acetate. II. Effects on follicular size and activity. J Reprod Fertil 1966; 11:193-201.

8. Guthrie HD, Lamond DR, Henricks DM, Dickey JF. Ovarian follicular changes in heifers treated with melengestrol acetate. J Reprod Fertil 1970; 22:363-364.

9. Hill JR, Lamond DR, Henricks DM, Dickey JF, Niswender GD. The effect of melengestrol acetate (MGA) on ovarian function and fertilization in beef heifers. Biol Reprod 1971; 4:16-22.

10. Chow LA, Thatcher WW, Chenault JR, Kalra PS, Wilcox CJ. Effects of MGA on bovine plasma ovarian steroids. J Anim Sci 1972; 35:239 (abstract).

11. Henricks DM, Hill JR, Dickey JF. Plasma ovarian hormone levels and fertility in beef heifers treated with Melengestrol Acetate (MGA). J Anim Sci 1973; 37:11691175.

12. Randel RD, Callahan CJ, Erb RE, Garverick HA, Brown BL. Effect of melengestrol acetate on rate of excretion of estrogen in urine of dairy heifers. J Anim Sci 1973; 36:741-748.

13. Kojima FN, Stumpf TT, Cupp AS, Werth LA, Roberson MS, Wolfe MW, Kittok RJ, Kinder JE. Exogenous progesterone and progestins as used in estrous synchrony regimens do not mimic the corpus luteum in regulation of luteinizing hormone and 17 $\beta$-estradiol in circulation of cows. Biol Reprod 1992; 47:1009-1017.

14. Beck TW, Smith VG, Seguin BE, Convey EM. Bovine serum LH, GH and prolactin following chronic implantation of ovarian steroids and subsequent ovariectomy. J Anim Sci 1976; 42:461-468.

15. Stumpf TT, Roberson MS, Wolfe MW, Hamernik DL, Kittok RJ, Kinder JE. Progesterone, 17 $\beta$-estradiol, and opioid neuropeptides modulate pattern of luteinizing hormone in circulation of the cow. Biol Reprod 1993; 49:1096-1101.

16. Roberson MS, Wolfe MW, Stumpf TT, Kittok RJ, Kinder JE. Luteinizing hormone secretion and corpus luteum function in cows receiving two levels of progesterone. Biol Reprod 1989; 41:997-1003.

17. Sirois J, Fortune JE. Lengthening the bovine estrous cycle with low levels of exogenous progesterone: a model for studying ovarian follicular dominance. Endocrinology 1990; 127:916-925.

18. Adams TE, Kinder JE, Chakraborty PK, Estergreen VL, Reeves JJ. Ewe luteal function influenced by pulsatile administration of synthetic LHRH/FSHRH. Endocrinology 1975; 97:1460-1467.

19. Wolfe MW, Stumpf TT, Roberson MS, Wolfe PL, Kittok RJ, Kinder JE. Estradiol influences on pattern of gonadotropin secretion in bovine males during the pe riod of changed responses to estradiol feedback in age matched females. Biol Reprod 1989; 41:626-634

20. Acosta B, Tarnavesky GK, Platt TE, Hamernik DL, Brown JL, Schoenemann HM, Reeves $\mathbf{J}$. Nursing enhances the negative effect of estrogen on LH release in the cow. J Anim Sci 1983; 57:1530-1536.

21. Steel RGD, Torrie JH. Principles and Procedures of Statistics. New York: McGrawHill Book, Co; 1980.

22. SAS. SAS User's Guide, Statistics (5th ed.). Cary, NC: Statistical Analysis System Institute, Inc,; 1985.

23. SAS. Changes and Enhancement: Technical Report, SAS/STAT Software. Cary, NC: Statistical Analysis System Institute, Inc.; 1992

24. Rahe $\mathrm{CH}$, Owens RE, Fleiger $\mathrm{L}$, Newton HJ, Harms PG. Pattern of plasma luteinizing hormone in the cyclic cow: dependence upon the period of the cycle. Endocrinology 1980; 107:498-503.

25. Walters DL, Schams D, Schallenberger E. Pulsatile secretion of gonadotropins, ovarian steroids and ovarian oxytocin during the luteal phase of the oestrous cycle in the cow. J Reprod Fertil 1984; 71:479-491.

26. Imakawa K, Day ML, Zalesky DD, Garcia-Winder M, Kittok RJ, Kinder JE. Regulation of pulsatile LH secretion by ovarian steroids in the heifer. J Anim Sci 1986; 63:162-168.

27. Enciso SA, Galina HC, Garcia-Winder M. Secretion of luteinizing hormone ( $\mathrm{LH}$ ) and progesterone $(P)$ in Bos taums $\times$ Bos indicus cows treated with three progestogens. Rev Ann Inv Pec Mexico 1990; 395 (abstract).

28. Chenault JR, Thatcher WW, Kalra PA, Abrams RM, Wilcox CJ. Transitory changes in plasma progesterone, estradiol, and luteinizing hormone approaching ovulation in the bovine. J Dairy Sci 1975; 58:709-717.

29. Stumpf TT, Day ML, Wolfe MW, Clutter AC, Stotts JA, Wolfe PL, Kittok RJ, Kinder JE. Effect of estradiol on secretion of luteinizing hormone during the follicular phase of the bovine estrous cycle. Biol Reprod 1989; 41:91-97.

30. Stumpf TT, Wolfe MW, Day ML, Stotts JA, Wolfe PL, Kittok RJ, Kinder JE. Effect of $17 \beta$-estradiol on the preovulatory surge of LH in the bovine female. Theriogenology 1991; 36:201-207.

31. Priedkalns J. Effect of melengestrol acetate on the bovine ovary. Z Zellforsch $1971 ; 122: 85-110$ 
32. Custer EE, Beal WE, Wilson SI, Meadows AW, Berardinelli JG, Adair R. Effect of melengestrol acetate (MGA) or progesterone-releasing intravaginal devices (PRID) on follicular development, concentrations of estradiol-17 $\beta$ and progesterone, and luteinizing hormone release during an artificially lengthened bovine estrous cycle. J Anim Sci 1994; 72:1282-1289.

33. Yelich JV, Geisert RD, Morgan GL, Hardin PL. Persistence of dominant follicle during melengestrol acetate (MGA) administration and regression induced by exogenous estradiol valerate treatment in beef cows. Biol Reprod 1993; 48(suppl 1):142 (abstract)

34. Stock $\mathrm{AE}$, Fortune JE. Ovarian follicular dominance in cattle: relationship between prolonged growth of the ovulatory follicle and endocrine parameters. Endocrinology 1993; 132:1108-1114.

35. Cupp A, Garcia-Winder M, Zamudio A, Mariscal V, Wehrman M, Kojima N, Peters K, Bergfeld E, Hernandez P, Sanchez T, Kittok R, Kinder J. Concentration of pro gesterone $\left(\mathrm{P}_{4}\right)$ in circulation has a differential effect on biochemical characteristics of dominant follicles in cows. J Anim Sci 1993; 71(suppl 1):211 (abstract).

36. Savio JD, Thatcher WW, Badinga L, de la Sota RL, Wolfenson D. Regulation of dominant follicle turnover during the oestrous cycle in cows. $\mathrm{J}$ Reprod Fertil 1993; 97:197-203.

37. Savio JD, Thatcher WW, Morris GR, Entwistle K, Drost M, Mattiacci MR. Effects of low plasma progesterone concentrations with a progesterone-releasing intra- vaginal device on follicular turnover and fertility in cattle. J Reprod Fertil 1993 98:77-84.

38. Wehrman ME, Roberson MS, Cupp AS, Kojima FN, Stumpf TT, Werth LA, Wolfe $\mathrm{MW}$, Kittok RJ, Kinder JE. Increasing exogenous progesterone during synchronization of estrus decreases endogenous 17/-estradiol and increases conception in cows. Biol Reprod 1993; 49:214-220.

39. Sanchez T, Wehrman ME, Bergfeld EG, Peters KE, Kojima FN, Cupp AS, Mariscal V, Kittok RJ, Rasby RJ, Kinder JE. Pregnancy rate is greater when the corpus luteum is present during the period of progestin treatment to synchronize time of estrus in cows and Heifers. Biol Reprod 1993; 49:1102-1107.

40. Neff AW. Analytical methods for MGA® (melengestrol Acetate). In: Anabolics in Animal Production (Public Health Aspects, Analytical Methods and Regulation). Paris, France: Office International des Epizooties; 1983: 457-485.

41. El-Fouly MA, Cook B, Nekola M, Nalbandov AV. Role of the ovum in follicular luteinization. Endocrinology 1970; 87:288-293.

42. Nekola M, Nalbandov AV. Morphological changes of rat follicular cells as influenced by oocyte. Biol Reprod 1971; 4:154-160.

43. Hubbard GM, Erickson GF. Luteinizing hormone-independent luteinization and ovulation in the hypophysectomized rat: a possible role for the oocyte? Biol Reprod 1988; 39:183-194.

44. Vanderhyden BC, Cohen JN, Morley P. Mouse oocytes regulate granulosa cell steroidogenesis. Endocrinology 1993; 133:423-426. 